\title{
Relocating Pastorian Medicine: Accommodation and Acclimatization of Pastorian Practices against Smallpox at the Pasteur Institute of Chengdu, China, 1908-1927
}

\section{Chien-Ling Liu}

Department of History University of California, Los Angeles

E-mail: chienlingliu@ucla.edu

\section{Argument}

Revising the diffusionist view of current scholarship on the Pasteur Institutes in China, this paper demonstrates the ways in which local networks and circumstances informed the circulation and construction of knowledge and practices relating to smallpox prophylaxis in the Southwest of China during the early twentieth century. I argue that the Pasteur Institute of Chengdu did not operate in a natural continuity with the preceding local French medical institutions, but rather presented an intentional break from them. This Institute, as the first established by the French in China, strove for political and administrative independence both from the Chinese authority and from the Catholic Church. Yet, its operation realized political independence only partially. The founding of this Institute was also an attempt to satisfy the medical demand for local vaccine production. However, even though the Institute succeeded at producing the Jennerian vaccine locally, its production needed to accommodate local conditions pertaining to the climate, vaccine strains, and animals. Furthermore, vaccination had to conform to Chinese variolation, including its social and medical practices, in order to achieve the collaboration of local Chinese traditional practitioners with French colonial physicians, who were Pastoriantrained and worked at the Pasteur Institute of Chengdu. Thus the nature of the Pastorian work in Chengdu was not an imposition of foreign standards and practices, but rather a mutual compromise and collaboration between the French and the Chinese.

\section{Introduction: The History of Pastorian Medicine in China}

The study of Pastorian medicine in China belongs at the juncture of the history of Western modern medicine in China, the modern history of traditional Chinese medicine, and colonial knowledge studies. Conventionally, the scholarship of modern history of traditional Chinese medicine focuses on the perseverance of traditional knowledge, whereas its counterpart in the history of modern medicine in China usually formulates a grand narrative, wherein modern Western medicine appears 
as an emanation of European hegemonic domination, operating exclusively under its auspices in a diffusion of medical science to China. Sean Hsianglin Lei argues that neither of these two characteristics is historically true, and today's so-called Chinese medicine and medical health care in China is a product that coevolved between traditional Chinese medicine and biomedicine (Lei 2014, 6). This revisionist account of the modern history of traditional Chinese medicine shows how traditional Chinese medicine changed through working within the state's modernization project by adapting scientific methods and strengthening itself through institutional efforts. Consequently, traditional Chinese medicine not only stands out as a unique case that survived the attack of science and modernity, but also flourished and became accepted into state-sanctioned public knowledge. Scholars following this line of inquiry place the practitioners of Chinese medicine and sometimes the medical missionaries at the center of their work (Lei 2014; Hanson 2010; Andrews 2014; Benedict 1996; Taylor 2005; Fang 2012).

Current scholarship has studied extensively the transmission of knowledge and practices, the techniques, as well as the production and preservation of miao (苗, scab or pustule matter of smallpox for variolation) in the history of variolation and vaccination in China during the Ming and Qing period up to the early nineteenth century $^{1}$ (Fan 1953; Leung 2012; Chang 1996; Moulin 1996; Qiu Zhonglin 2006). Placing the history of vaccination within the context of modern medicine in China, this trend of scholarship emphasizes civil activism, originated in Southern China and performed by philanthropic merchants and literati, as the primal force facilitating the dissemination of vaccination knowledge and practices. Recent scholarship has paid more attention to aspects of interactions and exchanges on the epistemological and socio-cultural levels. It connects modern medicine with colonial and local actors, including Anglo-American or Japanese colonial powers, and their medical institutions and personnel in China or Taiwan (Rogaski 2004; Bullock 1980; Li 1999; Shiyung Liu 2009). These medical institutions, such as the Chinese Maritime Customs Medical Service, and the Rockefeller-founded Peking Union Medical School and Hospital in Beijing, had British or American sponsors. Few studies have paid attention to other instances of European presence in China, with exceptions such as the French in the South and the Southwest of China (Bretelle-Establet 2002; Chien-Ling Liu 2016). Built on the current studies, this paper explores the circulation of knowledge and practices regarding smallpox prophylaxis on the institutional level with a transnational focus,

\footnotetext{
${ }^{1}$ The terminology used to describe the prevention of smallpox can cause confusion. "Inoculation" and "variolation" referred solely to inducing immunity against smallpox with human smallpox virus and were not interchangeable with "vaccination." The term "vaccination" was first used in late eighteenth century after Edward Jenner developed a smallpox vaccine derived from cowpox. From the nineteenth century on, the term "variolation" in English was used to avoid confusion with vaccination. In the late nineteenth century, Louis Pasteur honored Jenner by expanding the meaning of "vaccination," referring to the artificial induction of immunity against any infectious disease. "Inoculation" is also used as an equivalence of "injection" in connection with the use of vaccines but usually relating to laboratory work.
} 
mainly through the understudied Pastorian network in China at the beginning of the twentieth century. Geographically, this paper follows the French colonial physicians, representing non-Anglo-American actors, into the region that has not yet attracted much scholarly attention.

Recent inquiries into colonial knowledge studies have gone beyond ideas and theories, focusing on scientific and medical practices to emphasize the circulatory constitution of scientific knowledge and practices, and to recognize an asymmetric relationship within a colonial power structure. This trend of scholarship, focusing on scientific practices related to colonial knowledge, methodologically revises the conventional construal of the immutable nature of scientific knowledge, supposed to suffer no change through displacement and take no consideration of scientific practices in other cultures (Raj 2007; Kumar 1997; Anderson 2008; Lock and Kaufert 2001; Rheinberger 2016; Creager 2001; Wilson 2014). It argues that the mutable nature of the materials, along with their transformation and reconfiguration in the course of their geographical or socio-cultural displacement, constitutes the exchanges as the locus of formation of scientific knowledge and practices.

This paper builds on these lines of scholarship by focusing on a hitherto understudied group of French colonial physicians, who were part of the Pastorian community and received Pastorian training before working at the Pasteur Institute of Chengdu. ${ }^{2}$ I argue that it was implausible for these Pastorians simply to have imposed their medical practices in China. On the contrary, by looking at how practices had been shaped within environmental, political, and socio-cultural constraints, I have found that in order to carry out their medical work, these colonial physicians had to accommodate local circumstances and make compromises with local communities. These Pastorian

\footnotetext{
${ }^{2}$ In 1895, Maurice de Fleury, a French medical journalist, coined the term "Pastorians" (Pastoriens) to refer to the group of collaborators of Louis Pasteur in France during the final decades of the nineteenth century (De Fleury 1895). Current scholarship on Pastorians identifies them as Pasteur's immediate disciples and the following generations who completed the "Cours de Microbiologie" (Course of Microbiology), later (1922-1947) known as the "Grand Cours" (Grand Course), a program organized at the Pasteur Institute in 1889 by Émile Roux, a close collaborator of Pasteur and co-founder of the Pasteur Institute in Paris. These disciples included foreign nationals who studied in the same program, some of whom later worked in the Pasteur Institutes outside of France, either directly or indirectly linked with the Pasteur Institute of Paris. Anne-Marie Moulin applies the term "Pastorians" more broadly, to "a community of men of all origins dedicated to a common goal: the investigation of the bacteriological cause of diseases and the invention of preventive and curative methods such as sera and vaccines to fight such diseases" (see Moulin 1994, 333). In Chien-Ling Liu's study, the Pastorians in China during the period of 1899-1951 can be divided into three categories. The first includes the French colonial physicians assigned by the French government to work in the three Pasteur Institutes in China, one in Chengdu as in this paper, one in Tianjin, and the other at the French Concession in Shanghai. The English physicians who worked at the Shanghai Pasteur Institute in the International Settlement of Shanghai constitute the second category. The third category comprises the Chinese nationals trained in Pastorian sciences. Trained at the Pasteur Institute of Paris or the one in Saigon, these Chinese scientists and physicians were employed in medical research or public health works in China, whether at Pasteur Institutes or other medical institutions. Liu designated this third group as the "Chinese Pastorians," numbering around twenty in this period (see Chien-Ling Liu 2016).
} 
practices in China exemplified the content of Pastorism and the contrast between the French and Chinese understanding of science. This paper complements the current scholarship in finding that the Pastorians have displayed "intellectual mobility" since the late nineteenth century. It demonstrates that the contemporary Pastorians conformed their research and public health work to local contexts and identified their practice with empiricism and applications, as opposed to theories and pure science (Moulin 1992, 308). However, current scholarship attests that "Pastorians had little consideration for indigenous cultures" (Moulin 1995, 257). One might regard Pastorian medicine as an instance of modern Western medicine, given that the latter adopted the germ theory of disease and subsequently developed associated principles in vaccinology, immunology, and other fields. However, it becomes evident, as shown in this paper, that owing to its emphasis on localism, and the accommodation of environmental and socio-cultural factors in its practices, the Pastorians learned on the ground and incorporated local knowledge and conditions into their practices.

Led by French scholars, the study of history of the overseas Pasteur Institutes has paid much attention to the interwoven relationship between scientific imperialism and colonial expansion from the late nineteenth century up to the end of the Second World War, extending to the post-colonial era in some regions. These Pasteur Institutes outside of France included both the ones directly connected with the French Ministry of Foreign Affairs and the Pasteur Institute of Paris, as well as those that, though not officially connected thereto, followed the Pastorian methodology, mostly in rabies treatment and other microbiological studies and vaccine production. The thoroughly studied regions cover the regions in Asia, South and North America, and Africa. ${ }^{3}$ This trend of scholarship has revised the diffusion view of unilateral imposition of Pastorian knowledge into these areas and contests the universality of Pastorian methods.

In this body of scholarship on Pastorian networks, the study of the Pasteur Institutes in China remains largely unexplored. The sole contribution here before the end of the Second World War is made by French historian Marianne Bastid-Bruguière (BastidBruguière 1991). Her research thoroughly explores the French sources and clearly lays out the political background of the establishment of the Pasteur Institutes in China. However, it interprets the establishment and operation of the Pasteur Institutes in China before 1922 as a purely Parisian initiative, and the transplantation of Pastorian knowledge to China in the following years as a "failure" in contrast to the success of scientific works elsewhere, particularly in French Indochina (ibid., 254 and 165; Moulin 1995, 250). In writing the comparative history of the overseas Pasteur Institutes, AnneMarie Moulin and Jean-Pierre Dedet follow Bastid-Bruguière's study to portray the case in China (Moulin 1992; Moulin 1994; Moulin 1995; Moulin 2004; Moulin et al. 2008; Dedet 2000). They agree with her assessment of the inefficiency of the Pastorian

\footnotetext{
${ }^{3}$ The studies of the Pasteur Institutes in Asia include Guénel 1999 and Chakrabarti 2012. Regarding the ones in South and North America, see Löwy 1990 and Wang 2013. The works on the ones in Africa include Moulin 1991; Peltier 1947; Pelis 1997; Lachenal 2011; Rosenberg 2012; and Strachan 2006.
} 
project in China and mention in passing to the "local drive" and adaptation that complemented the French policy to extend its sphere of influence (Moulin 1992, 316). With the evidence of Pastorian localism, this paper offers an in-depth view of Pastorian practices in China. The body of knowledge within the Pastorian network was based on a commonality of empirical methods, which yielded scientific results. I argue that these results underwent many changes in China, challenging the understanding of science for the European Pastorians. Specific local social and cultural features modified various medical practices. The nature of Pastorism, in this sense, was constantly reinvented and reconstituted in local contexts. ${ }^{4}$

This paper tells the story of how the French Pastorians took into account and accommodated local specificities in their medical practices, in the context of Jennerian vaccine production and vaccination campaigns of smallpox prophylaxis, undertaken at the Pasteur Institutes in Chengdu during the early twentieth century. Of particular concern is how they accounted for the climate, geographical distance, and acclimatization of animals and vaccine strains, a process whereby a living organism adapts to gradual changes in the natural local environment. For instance, in selecting animal vaccine producers, Albert Calmette, the founder of the Pasteur Institute in Saigon of French Indochina, concluded from his experiments that local water buffaloes were best suited for this purpose. His successors relied exclusively on water buffaloes as their source of vaccine production in the Far East. However, the Pastorians in Chengdu found that the local water buffalo in Sichuan resisted infections much better than its counterpart in French Indochina. They also discovered that local heifers could serve as a reliable source of vaccine when water buffaloes were scarce. Moreover, in order to acquire local animals, the Pastorians had to negotiate with local Muslim farmers, accommodating disparate cultural perceptions and attitudes.

Beyond such environmental considerations, in addition to working with the local Chinese authorities and Catholic missionaries, the French Pastorians conducting Jennerian vaccination at the Pasteur Institute of Chengdu had to collaborate with local Chinese practitioners in disseminating a prophylactic measure that incorporated traditional Chinese variolation practices. On the one hand, they accommodated the Chinese preference of inserting Jennerian vaccine into acupunctural points, performed vaccination against smallpox in the spring, and coordinated vaccination with the worship of the Smallpox Goddess. ${ }^{5}$ On the other hand, the Pastorians deemed their work scientific because of its empirical nature that followed Pastorian guidelines and

\footnotetext{
${ }^{4}$ The localizing nature of Pastorism accords with Michael Osborne's study on the development of the French navy medicine, localizing concepts of diseases according to local conditions (see Osborne 2014).

${ }^{5}$ These Sinicized methods, which included inserting vaccine into acupunctural points and utilizing vocabularies from traditional Chinese medicine and familiar ways of explanation to be more accessible for the Chinese to accept the western technique, were originated in Canton and then transmitted throughout Southern and then Northern China (see Qiu Xi [1817] 2002; Chen Yuan 1993, 780-781; Chang 2007, 774-775, Leung 1996, Leung 2008, and Leung 2012). This paper will specifically illustrate the particular modified Sinicized methods in the Southwest of China.
} 
standards, which was to administer the attenuated pathogen in order to control and even eradicate an infectious disease, notwithstanding various local adaptations. They regarded their accommodation of the natural and social environment as an integral part of Pastorian practices.

\section{Indirect Imperialism: The French Pastorians in the Southwest of China}

Accompanied by his wife, Aimé-François Legendre - Physician Major of the first class in the French colonial troops leading the French medical mission - arrived in Shanghai in 1902 from Phulang-Thuong in Tonkin, French Indochina, and traversed approximately two thousand miles on the Yangtze River westwards to Chengdu, where the first French-founded Pasteur Institute in China eventually opened in 1908. A crucial duty of these Pastorian-trained physicians in Legendre's medical team and later at the Pasteur Institute of Chengdu, consisting of the physicians of the French Colonial Medical Service (Corps de Santé Colonial, created in 1890, later the Corps de Santé des Troupes Colonial), was to investigate the bacteriological causes of diseases and implement their prophylaxes with vaccines, mainly against smallpox and rabies ${ }^{6}$ (Legendre 1905, 15). In contrast to the theoretical lecturing teaching style that prevailed at other contemporary French universities, these Pastorian-trained colonial physicians mastered microscopic skills and microbiological knowledge by adapting the lessons of their training based on experimentation and clinical work according to local colonial conditions, while making theoretical advances in the germ theory of disease

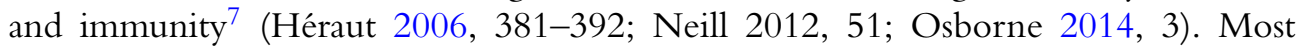

\footnotetext{
${ }^{6}$ From the early 1920 s to the late 1940 s, the Pastorians at the Pasteur Institutes in China worked under the auspices and funding of the French government in collaboration with Chinese authorities, with an exception of the Shanghai Pasteur Institute at the International Settlement in Shanghai that had been founded under the British government. They all pursued their official agenda, namely conducting microbiological research on infectious diseases, producing vaccines, and providing services, such as vaccination and analysis of food and water, in the interests of public health. Founded respectively in 1899 and 1908, the Shanghai Pasteur Institute at the International Settlement and the Pasteur Institute of Chengdu were complemented by the Pasteur Laboratory of Tianjin in 1922 and the Pasteur Institute of Shanghai at the French Concession in 1938. While the Chengdu facility closed in 1944, foreign control in other three Pasteur Institutes continued until the Communist government took over Mainland China. The last one to have its foreign staff and funding moved away was the Pasteur Laboratory in Tianjin in 1951. During the Republican era, these Pasteur Institutes provided the services that the Chinese Nationalist government, which maintained political control over much of China from 1927 to 1948, could not always deliver due to limited resources and political turbulence. These services included treating rabies patients, developing and supplying vaccines against smallpox, cholera, tuberculosis, and other infectious diseases, and conducting public health campaigns (see Chien-Ling Liu 2016, 27).

${ }^{7}$ The French military medical personnel working for the Colonial Medical Service followed maritime medical tradition, focusing on colonial medicine, and noting a special sort of medical practice in virtue of its content, patients, practitioners, disease, and geographical locations. Since 1890, they received their training at the Naval Medical School (École de Santé Navale, short for École Principale du Service de Santé de la Marine) in Bordeaux, the centralized institution in charge of all naval schools, including the ones in Rochefort, Brest, and Toulon. Later on, the training shifted to the School of Colonial Medicine (École d'Application du Service de Santé Colonial), in
} 
importantly, they pledged to discover the "other" human cultures in the places they served (Héraut 2006, 382). Treating his Pastorian training as a method for approaching the truth, Legendre disparaged some of his European predecessors and contemporaries who usually depicted the Chinese as "strange, stupid, incomprehensible," as they circulated stereotypes thoughtlessly fabricated without ever bothering to set foot on their territory. ${ }^{8}$ Instead, along with his Pastorian colleagues in China, Legendre aimed to show the Chinese as they were in life, free of disguise. Therefore, he travelled to China, learned the Chinese language, made contacts with the local Chinese, and observed them "scientifically" (Legendre 1905, 8, 17-18).

Based on his observations, made in the contemporaneous context of growing international trade and communication, Legendre urged the government and the general public in France, to connect with China and her people through exploring her rich resources and markets as an effective alternative to the ongoing colonial pursuits in Africa. Legendre saw this development as crucial for the destiny of France. Connecting with China was a matter of "current necessities, both political and economic," which would help France become more competitive with other imperialistic powers (Legendre 1905, 11-13). Many functionaries at the French Ministry of Foreign Affairs had agreed with Legendre's view. Since 1901, the Committee of the French Asia (Comité de l'Asie Française) within the French Ministry of Foreign Affairs had aimed to establish a vast French Asian Empire rooted in French Indochina (conquered in 1887), spreading west into Thailand and north into China (Abrams and Miller 1976, 687). The specific region in China that Legendre had in mind was Sichuan, a province

brief called the Pharo (École du Pharo, as it was located in the Pharo, a district of the seventh arrondissement in Marseille), which was founded in Marseille in 1905 and started accepting students in 1907. Before becoming colonial medical officers, these trainees also studied at the Pasteur Institute of Paris, specifically taking the course of microbiology. For instance, having received Pastorian education with the French maritime medical tradition in his background as many of his colonial colleagues, Legendre studied at the Naval Medical School in Bordeaux and under Émile Roux at the Pasteur Institute of Paris. See "Lettre du Docteur A. Legendre au Consul Général à Tchentou - Annexe à la lettre no. 43, en date du 23 Septembre 1907, du Consulat Général de France à Tchentou à la Direction Politique," 21/09/1907, 4-5, Chine 656, Nouvelle Série (NS), Archives du Ministère des Affaires Étrangères, La Courneuve, Paris (MAEP). Regarding the education of Pastorian-trained French colonial physicians since the late nineteenth until the end of WWII, see Héraut 2006; Faure 1991, and Osborne 2014, 2, 50 and 107. For the educational background of the French Pastorians in China and the Pastorians of Chinese nationals in particular, see Chien-Ling Liu 2016, 42-46.

${ }^{8}$ G. Eugène Simon was one of the targets of Legendre's polemics: "Thus the Chinese whom I have described are very different from those described by Eugène Simon, for example. [I think] that the physician, through ingrained habits, ought to mistrust the surface appearances to the highest degree and ruthlessly probe the internal organs. And having established his diagnosis after a thorough elimination of all the available erroneous alternatives, he must continue to observe and examine the subject anew and defer the definitive acceptance of his original conclusions until they have been ratified in the long term by the brutality of facts" (see Legendre 1905, 17-18). Simon was an agricultural engineer, who undertook a four-year mission to China in the early 1860s. Legendre did not challenge Simon's experience of actually having been in China but disagreed with his depiction of the Chinese people. I found no further evidence of what exactly Legendre questioned in Simon's account. Judging from the above quote, it might have had something to do with how a physician ought to proceed in his work. 
located in the Southwest of China, which ensured "the best conditions [for] rapid and complete development of [the French] Indochinese colony" (Legendre 1905, 14). Indeed, as a result of political and economic calculation, Sichuan had been designated a colonial strategic point at the Quai d'Orsay, the headquarters of the Ministry of Foreign Affairs in France. Taking advantage of its location and resources, the French established the Pasteur Institute of Chengdu, in the capital of the Sichuan Province, also in consideration with countering other colonial influences, including those of Britain, the United States, Canada, and Japan (Barbier 1997, 132-134).

There remained one problem though: as Legendre observed, owing to their historical recollection of the European imperialistic expansion in China since the midnineteenth century, many common Chinese people complained that "the European rule is to attack, not to persuade" (Legendre 1905, 10). Legendre agreed with them, pointing out that "the great mistake of the white race is thinking that its civilization, its creative power, and its machines impose themselves, dazzle the other races, open all vistas, and dispel all darkness. This is a serious delusion, all the more tenacious and dangerous because it flatters [the Europeans'] pride, which is as boundless as that of the Chinese." In order to counter this ill impression of the Europeans, Legendre proposed to rely on science. Thus scientific medicine became the main instrument of his civilizing mission. (ibid., 10-11)

However, what constituted scientific medicine? At the turn of the twentieth century, the practitioners of modern medicine argued that Western medicine had become "scientific," insofar as it relied on more systematic anatomico-pathological observations and repeatable experiments, as well as evidence collected in empirical tests and clinical practice. The germ theory of disease emerged under the rubric of scientific medicine, tracing the aetiology of certain diseases to pathogenic microorganisms. Issues of public health, along with studies of infectious diseases and immunity the ability to withstand or resist infection, disease, or other biological invasion became the central focus of scientific pursuit conjoined to European political and economic development and imperial expansion. This was where "Pastorian medicine" came in. Following the empirical guidelines of Louis Pasteur and his followers, it defined its mission of controlling, if not eradicating, infectious disease by inducing immunity or resistance through administering the pathogen in an attenuated form. From the 1880s on, Pastorian medicine had grown through support by the French government and the international community, despite resistance from anti-vaccination and anti-vivisection movements. Hopeful of regaining France's prestige lost through the Franco-Prussian War (1880-1881), the French government supported the scientific

\footnotetext{
${ }^{9}$ In the late 1890s, the French Ministry of Foreign Affairs aimed to compete with British influence in Sichuan and Paul Doumer, the Governor-General of French Indochina, planned to expand the railway from Indochina to Yunnan, and even to Sichuan. The Kunming-Haiphong Railway was built after 1910, connecting Haiphong in Indochina with Yunnanfou (nowadays Kunming 昆明) in the Yunnan province in China, but the connection to Sichuan never happened under French colonial rule (see Barbier 1997, 132-134).
} 
expansion by Pasteur and the Pasteur Institute, first in Paris and later worldwide. As part of its political policy of secularism (laicite), the Third Republic attempted to replace the traditional Catholic faith with the gospel of science, in particular with Pastorian medicine (Moulin 2004, 141). Since the establishment of the Pasteur Institute in Paris in 1888 and the inception of its course of microbiology in the following year, both French and foreign physicians played a vital role in the dissemination of Pastorian medicine in Europe and elsewhere (Faure 1991, 65). From 1891 on, Pastorian-trained French colonial physicians promulgated it as part of their civilizing mission with the agenda of scientific imperialism, by conducting their work at overseas Pasteur Institutes in Asia, Africa, Americas, and Oceanic countries (Moulin 1992, 307).

The French colonial policy of "indirect imperialism" aimed to spread French cultural, economic, and political influence as an alternative to military conquest (Abrams and Miller 1976, 687). This science imperialism manifested itself and attempted to impose its principles through the Pastorian network (Moulin 1992, 307). It was in this context that the French government regarded Pastorian medical work as one of the most effective strategies of scientific expansion at the outset of this new colonial policy, especially in the areas where the French did not have formal colonial control, including the Southwest of China. ${ }^{10}$

The actual practices of adopting the Pastorian principle, however, varied widely in different locations. Although the colonial office in Paris could not have anticipated all of the local conditions, it relied upon these physicians' experiences to inform its understanding of the local circumstances of infectious disease and public health for making decisions concerning specific colonial policies. These policies included designating circulating routes for the supply of vaccines, coordinating with various French or international colonial posts to put in place public health measures against epidemics, training local physicians in existing neighboring Pasteur Institutes, and so forth. In China, the Pastorians confronted a panoply of specificities in local environment, politics, religion, and social customs, as well as medical culture and its associated knowledge and practices. Thus they had to adapt and modify their Pastorian methods in response to these local conditions.

Concerning the local reality, the French civilizing mission was in the nature of constant negotiations. Prior to the establishment of the Pasteur Institute in Chengdu in 1908, the French medical mission led there by Legendre in Chengdu since 1902 was not directly in charge of local French-associated medical institutions. These institutions namely the Chinese Medical School (École de Médecine Chinoise), the School of Arts and Crafts (École des Arts et Métiers), and the Catholic Missionary Hospital (Hôpital de la

\footnotetext{
${ }^{10}$ French physicians and their medical work were documented in the following areas in China: First were the territories of Guangzhou Wan 廣州灣 (1898-1946) and Xiamen Dao 廈門島 (1859-1949), the only two official French colonies in China in this era. The others included the official sphere of French influence recognized by China: provinces of Yunnan, Guangxi, Hainan, Guangdong. Moreover, the French had three concessions, in Shanghai (1849-1946), Tianjin (1860-1946), and Hankou (1898-1946).
} 
Mission Catholique) - operated through collaboration between the Chinese authorities and the French government. The French medical mission employed five members, three physicians and two nurses, all with military rank. ${ }^{11}$ The medical mission was meant to reinforce the dissemination of vaccination through training the Chinese students at the two affiliated schools, as well as dispensing medical services at the hospital. However, the French physicians had to defer to the Chinese authorities in these two schools, while being constrained by the Catholic Mission in the hospital.

The position of the French colonial physicians in these institutions was far from secure, as their contracts were often allowed to expire without renewal if not breached beforehand. The authority of the Catholic Missionary Hospital did not adequately serve the goals of these French physicians. From the physicians' point of view, their medical work was meant to treat patients regardless of the nature of their illness. Stressing that the Catholic Mission preferred to dedicate its limited resources to religious conversion of the local population, the French physicians accused its missionaries of being reluctant to treat patients suffering from acute illnesses. Also, they observed that Chinese elites rarely used the medical services offered by the Catholic Missionary Hospital because they were averse to Christian religious institutions. ${ }^{12}$ Under these circumstances, the French physicians repeatedly petitioned the French Council and the French Ministry of Foreign Affairs to secure their positions and guarantee their autonomy. ${ }^{13}$

In addition to the political difficulties, the French colonial physicians also had to face medical challenges. The first such challenge concerned the seemingly incompatible conceptions of "contagion." Since the tenth century up to the first half of the twentieth century, the Chinese believed that people inherited the fetal toxin (tai $d u$ 胎毒) before birth, and as long as it remained quiescently lodged within the body, that element was not contagious itself. The spread of smallpox depended on direct contact with the smallpox seasonal vapor (shi qi 時氣, disorderly climatic conditions), which could be shifted from one person to another. Therefore, the seasonal vapor acted as the medium that made smallpox seem “contagious” (傳染, spreading illness from one person to another) (Chang 2000, 37). At the turn of the twentieth century, Jules Regnault, French colonial physician posted in Tokin of French Indochina, where local medical practice mainly drew upon Chinese medicine, came close to understanding the Chinese notion of "contagion." He observed that during the epidemic or on occasions of variolation performed within a household, the Chinese sprayed and fumigated the house to get rid of foul air, and burned contaminated objects, to countervail the smallpox seasonal vapor and prevent the spread of smallpox. The fumigation was often performed in

\footnotetext{
11 "Lettre du Docteur A. Legendre au Consul Général à Tchentou,” 21/09/1907, 4-5, Chine 656, NS, MAEP.

${ }^{12}$ Concerning the missionaries considering prevention less demonstrative of good will than the cure, see Andrews 2012, 179; Harrison 2013, and Harrison 2012. The French physicians observed that the Chinese elites abstained from going to both Catholic and Protestant hospitals. The Protestant hospitals also treated mostly the lower classes.

${ }^{13}$ Aimé-François Legendre, "Rapport du Dr. Legendre au Sujet de l'Hôpital Catholique de Tchen-tou, du Docteur Aimé-François Legendre au Ministre des Affaires Etrangères,” 26/05/1908, 5, Chine 651, NS, MAEP.
} 
conjunction with religious rituals meant to ward off evil spirits (Regnault 1901, 64). By contrast, judging by the germ theory of disease, H. Jouveau-Dubreuil, Director of the Pasteur Institute in Chengdu during 1911-1920, concluded that the Chinese were unaware that smallpox was "contagious," in the sense that the disease was spread by the smallpox pathogen. He observed patients continuing to live with their family and sometimes even having physical contact with their neighbors. No one protested these arrangements or attempted to quarantine inoculated children, who traversed the city on the way to the hospital in hired sedan chairs, which did not undergo any disinfection (Jouveau-Dubreuil 1921, 96-97). The concept of Chinese "contagion" spreading smallpox through the seasonal vapor - was different from the understanding of "contagion" in the germ theory of disease. ${ }^{14}$

The second medical challenge that the French physicians confronted was the failure of vaccination due to the low potency of a vaccine that was procured elsewhere and degraded owing to lengthy transportation and inadequate preservation. During 1908-1910, the success rates of the primary vaccination averaged only 20 percent among adults and 50 percent among newborns. ${ }^{15}$ At this rate it could not compete with the repute of the Chinese variolation practice, as the Chinese believed that the success rate of variolation could reach as high as 99 percent (Wong and Wu 1973, 276). The low potency of Jennerian vaccine diminished its capacity to guarantee permanent immunity due to its attenuated virulence. The French colonial physicians considered revaccination every three years to be necessary in order to renew immunity. However, the local patients were reluctant to revaccinate, even after they underwent an initial vaccination (Jouveau-Dubreuil 1920, 65-66). The medical culture of variolation appeared so deeply ingrained that it affected the local concept of revaccination. Chinese

\footnotetext{
${ }^{14}$ In Chinese medical understanding, chuanran referred to "an acute and widespread outbreak of epidemic or an infection spread through direct and intimate, person-to-person contact" (emphasis added). The Chinese perceived the different modes of transmission between contagion and infection with a dichotomous notion that "contagion is direct by [physical] contact [with the sick], and infection indirect, through the medium of water, air, or contaminated articles" (see Lei 2010, 88-90, and Pelling 2001, 15).

${ }^{15}$ Jean-Paul Esserteau, "Rapport pour l'Année 1909," 51, Chine, 656, NS, MAEP. According to the contemporary understanding, "vaccinia" or a "take" was considered as the primary vaccination, which was usually seen in people who had never previously been vaccinated or whose immunity from previous vaccination or naturally occurring smallpox had completely disappeared. The appearance of a papule appeared on the third to fifth day after vaccination and height of reaction was usually reached on the ninth or tenth day. In addition to the primary vaccination, there were other reactions, such as the vaccinoid reaction and immune reaction. The former was also known as accelerated or partial reaction. It was usually seen in people retaining partial immunity from a previous vaccination or a prior attack of smallpox. A papule appeared on the third or fourth day of vaccination with vesiculation. The height of reaction usually occurred on the sixth or seventh day, after which it rapidly subsided. The immune reaction, also known as immediate reaction or reaction of immunity, which was seen in people with active immunity, possibly resulted from recent vaccination. A papule appeared within two days and subsided without forming a vesicle (see "The Reactions Which Follow Smallpox Vaccination," Baltimore Health News 8, 4-5 (1936). U1-16-2654. Shanghai Municipal Archives). The aforementioned success rate, however, is questionable. It was difficult to check the results of vaccination. The French physicians could not obtain the results from the local vaccinated people, as the turnout of the returning patients was low (see Jean-Paul Esserteau, "Rapport pour l'Année 1910," 23, Chine, 656, NS, MAEP).
} 
physicians believed that once the fetal impurity was expelled, the body became purified and contained no more toxins in need of expulsion. Therefore, they rarely revaccinated their patients. In consequence, the French physicians' insistence on revaccination had little effect (Jouveau-Dubreuil 1921, 96).

Under these complex circumstances of political and medical struggle, these French physicians found it necessary to ensure vaccine quality by producing it locally and also to demonstrate their competence at preventing the disease. Advocated by Calmette, the project of establishing the Pasteur Institute of Chengdu was finally launched in 1908. Its establishment depended upon the political maneuvering undertaken in France by the Consul of Chengdu Pierre Bons d'Anty and Philippe Berthelot, Deputy Director of Asia and later the Minister of Foreign Affairs, as well as upon the funding provided by Robert Lebaudy, a French sugar industrialist (Bastid-Bruguière 1991, 256). However, even though the Pasteur Institute of Chengdu operated under the French direction, it had to collaborate and negotiate with the Chinese authorities. Before the fall of the Qing dynasty in 1911, the Pasteur Institute of Chengdu depended on maintaining good guanxi 關係 between the French Consulate and the viceroys of Sichuan and that of other surrounding provinces. ${ }^{16}$ The political situation became even more complicated after 1911, in the course of armed conflicts among the Chinese warlords of Sichuan and the neighboring provinces, especially Yunnan 雲南 and Guizhou 貴州 (Sheridan 1977; Bonavia 1995; Cun cui xueshe 1977; Kuang 1991; Sichuansheng wenshi yanjiu guan 2011). Consequently, political concerns informed the decisions of the French Consul and the Pasteur Institute's medical services in Chengdu. ${ }^{17}$ In other words, the Pasteur Institute in Chengdu could attain only partial political independence, given that it still had to rely on collaboration with local Chinese authorities.

Upon the establishment of the Pasteur Institute of Chengdu, the Pastorians in France authorized it to perform local microbiological studies and produce anti-rabies and Jennerian vaccines. ${ }^{18}$ The Institute partially lived up to these expectations until

\footnotetext{
${ }^{16}$ Guanxi 關係 is an untranslatable Chinese concept, describing a dynamic in personalized networks of relationships or connections that an individual cultivates with others. The term largely originated from Confucianism, which stresses the importance of associating oneself with others in an order of social relations, with an emphasis on implicit mutual obligations, reciprocity, and trust, in order to maintain the social and economic order of a society (see Gold 2002, 6 and 63).

${ }^{17}$ See Bodard 1999. This autobiographical fiction by the son of the French Consul, Albert Bodard, describes a complex relationship among the French consulate of Chengdu, the warlords in Sichuan, Yunnan, and Guizhou, and the governor general of French Indochina, between 1917 and 1921. The French tried to maintain a mutually beneficial connection with warlords in Yunnan and Guizhou, aiming to extend the railroad from Yunnanfou to Chengdu, and to oppose the English and their allied warlords in Sichuan. However, the French constantly had to deal with uncertainty, as well as negotiate and compromise with local warlords (also see Gervaise 1934). Serving as a colonial physician, Albert Gervaise practiced and taught medicine in Sichuan from 1911 to the 1920s. In this autobiographical work, he focused on his experiences along the Yangtze River. It includes several accounts of his exchange with the local warlord regarding the prevention or treatment of diseases, such as cholera.

18“Devis et Lettre de P. Lequeux, Paris," 25/09/1907, 77-79, Chine 300, NS, MAEP; "Projet d'Installation d'un Institut Pasteur à Tchen-tou," CHN01, 004, Archives de l'Institut Pasteur; “Organisation d'un Institut Pasteur à Tchentou," 9, Chine 651, NS, MAEP.
} 
1927, when it was forced to close. ${ }^{19}$ Even though the French government reorganized and reopened the Institute in 1929, it could not continue its mission for long and the Institute was permanently shut down in 1944.

Local production of Jennerian vaccine at the Pasteur Institute of Chengdu was meant to solve the problem of its questionable quality, as experienced earlier when it was shipped from elsewhere, suffering degradation due to uncontrollable temperature and long transportation. For instance, shipping the Jennerian vaccine from Saigon to Chengdu via Hong Kong usually took thirty to forty days, causing it to undergo a considerable loss of virulence. Manufacturing the vaccines locally in temperate seasons would avoid this obstacle (Jouveau-Dubreuil 1920, 64).

In the early twentieth century, the Jennerian vaccine production at the Pasteur Institute of Chengdu was significant. It was the only institution producing Jennerian vaccine in Western China, and its geographical location was convenient to supply the surrounding provinces, including Guizhou, Yunnan, Shaanxi 陝西, and Gansu 甘肅. Vaccine production increased sharply each year, from 4,000 doses in 1910, to about 100,000 doses in 1918-1919 and 378,900 in $1926 .{ }^{20}$ The success rate reached 98 percent in children in 1919, and 100 percent in 1926. The increasing amount of pulp delivery sufficed to serve Sichuan, even after its population reached 100 million in 1919 (Jouveau-Dubreuil 1920, 67-68, 75-76). From the late 1910s until 1927, the Pasteur Institute of Chengdu supplied Jennerian vaccine to most of the European and American medical services in Sichuan, including French, English, Canadian, and American hospitals, which previously received their vaccine from Shanghai, Hong Kong, or Japan.

In addition to the public health services in China at the time, the Pasteur Institute of Chengdu presented itself as one of rare institutions to play a crucial part in such a needed task. Prior to WWII, Chinese public health institutions, including the North Manchuria Plague Prevention Service from 1910, the Central Epidemic Prevention Bureau from 1919, and the Chinese Quarantine Service in the 1930s, were all funded and controlled by the Chinese Customs Service led by the British, and also funded by charities in the United States, such as the Rockefeller Foundation. The rural public health initiatives by the Chinese Nationalist government were still very much in the initial stages at the time of the Japanese invasion in 1937. Also, a survey of modern rural public health practice, carried out by the Chinese Medical Association Council on Public Health in 1934, found only seventeen rural public health centers, all of which were located on the east coast of China (Andrews 2012, 189-190). The Pasteur

\footnotetext{
${ }^{19}$ The anti-rabies vaccine could not be made locally in the Pasteur Institute of Chengdu until 1926. Between 1926 and 1927, the number of rabies treatments was limited to seven cases. The Chengdu Pastorians attributed that to rabies having been supposedly uncommon in Sichuan (P. Jouvelet, "Rapport sur le Fonctionnement de l'Institut Bactériologique de Tchentou pendant l'Année 1926,” 22/02/1927, 175-176, Chine, Série E, Asie, 500. MAEP).

${ }^{20}$ Jouvelet, "Rapport sur le Fonctionnement de l'Institut Bactériologique de Tchentou pendant l'Année 1926," 22/02/1927, 174, Chine, Série E, Asie, 500. MAEP.
} 
Institute of Chengdu in the Southwest of China stood out as the sole non-AngloAmerican Western institution, leading public health work against smallpox in this part of rural China.

\section{Making the Local Vaccine against Smallpox: Circulation and Acclimatization}

Vaccine strains coming from France and French Indochina were optimal for producing the local vaccine against smallpox in Chengdu, which was far removed from any other vaccinogen centers. The first vaccine strain came to the Pasteur Institute of Chengdu in March 1911 from the Vaccinogen Institute of Thai-Ha-Ap in Tonkin, French Indochina. That vaccine retained its potency for two years. In 1913, owing to the lack of refrigeration, the vaccine lost its virulence after being stored at room temperature throughout the summer. Its replacement came from the same institution and the supply continued until 1920 (Jouveau-Dubreuil 1920, 73-74). In 1917, Jouveau-Dubreuil traveled back to Chengdu from Paris after acquiring ten tubes of dry vaccine, equal to five hundred doses, from the Institute of Animal Vaccine (Institut de Vaccine Animale), founded in Paris in 1864 as the first organization to produce cowpox vaccine in France. Additionally, in 1919, Lucien Camus, the Director at the Institute of Vaccine (Institut Supérieur de Vaccine) in Paris, sent Jouveau-Dubreuil another batch of desiccated vaccine. Speculating about the relative efficiency of desiccated vaccine with respect to the glycerin one, Jouveau-Dubreuil tested them on local children and water buffaloes. The results exceeded his expectations. The two strains produced equally good results, measured in terms of the dimensions and confluence of the pustules. He then mixed the two strains and used this mixture from the late 1910s and throughout the 1920s (Institut de Vaccine Animale 1895, 1). The vaccine strains could be circulated, and even mixed locally to produce new strains within the imperial network spanning Paris (France), Tonkin (French Indochina), and Chengdu (China). Thus the Pasteur Institute of Chengdu became an important vaccinogen center in the Southwest of China.

In contrast to the foreign provenance of the vaccine strains that were eventually adapted locally, the local species of vaccinifers - the animals used for producing vaccine performed better in local applications than those delivered from afar. Based on his practice in French Indochina, Calmette successfully adapted the Paris cowpox strain to the local water buffaloes and concluded that these animals were preferable to heifers as vaccine producers (Calmette and Lepinay 1908). Subsequently, all of the vaccinogen institutions in the Far East relied upon water buffaloes. However, the Pasteur Institute of Chengdu found that the Sichuan water buffalo resisted infections much better than the ones in French Indochina. More interestingly, the local breed of heifers in Sichuan could substitute for water buffaloes as a good vaccinifer whenever the latter were in a short supply. The adoption of local heifers in Chengdu proved the efficacy of local acclimatization once again. Jouveau-Dubreuil found that although 


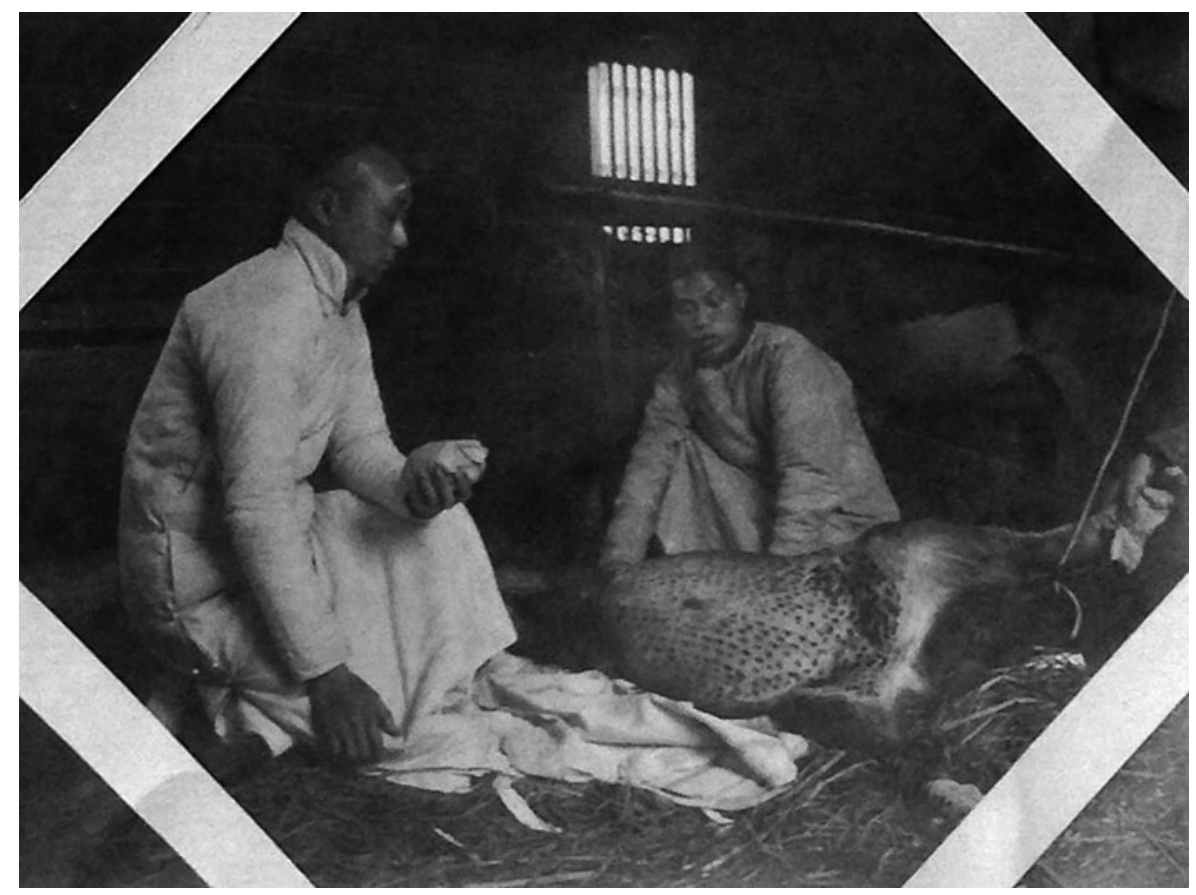

Fig. 1. Heifer Vaccination at the Pasteur Institute of Chengdu. Source: Essertau, "Rapport pour l'Année 1910," 81, Chine, 656, NS, MAEP.

the heifers in French Indochina tended to be small and feeble, their counterparts in Sichuan, where local farmers bred them to rival the European ones in size, were much stronger (Jouveau-Dubreuil 1920, 73). Moreover, the Sichuan heifers reacted to vaccination much better than those in French Indochina. In 1908, Marie-Joseph Mouillac, one of the French colonial physicians in Chengdu, tested and inoculated a heifer before students in the Chinese Medical School (see fig. 1). The heifer developed a few pustules, whereupon Mouillac vaccinated four soldiers with its pus dissolved in glycerin. One of these vaccinations succeeded, whereas the other three produced no reaction. Mouillac attributed the failure to the patients having been variolated before, rather than the lack of potency in the vaccine (Mouillac 1908, 18). In 1911, Jouveau-Dubreuil vaccinated fourteen heifers with the vaccine strain from Tonkin. The average harvest was satisfactory. He concluded that the Sichuan heifers would become useful whenever there was a shortage of water buffalo, as happened in 1918 and 1919 (Jouveau-Dubreuil 1920, 73).

At first, the Pasteur Institute of Chengdu met with trouble in procuring local water buffaloes. In negotiations with local Muslim farmers, the French Pastorians had to take into account their assessment of the intrinsic value of these animals, as well as their price, selection, and availability. In his 1910 report, Jean-Paul Esserteau, Director of 
the Pasteur Institute in Chengdu during 1908-1911, recounted the reluctance of the local farmers to lend cattle to him. They were concerned that the animal would lose its value after vaccination and no longer realize a good price in trade. Esserteau asked the missionaries to help him. For example, a missionary who lived a four-day walk away in a village southwest of Chengdu did not receive a favorable response from the local Muslim butchers, who demanded too high a price or refused to sell altogether. He also requested three more missionaries in other villages to find out if they could get a better deal. ${ }^{21}$ The archival documents do not show the final response of these three. From these exchanges we can infer that cross-cultural factors should also be taken into account in the process of acquiring the animal. It was not a purely economic transaction.

According to Jouveau-Dubreuil, the temperate nature of the local climate aided the transportation and preservation of the glycerin vaccine. During most of the spring and autumn, and throughout the winter, the outdoor temperature remained below $15^{\circ} \mathrm{C}$. Even though the temperature could reach as high as $30^{\circ} \mathrm{C}$ in summer, given adequate insulation and reliable postal service, the vaccine preserved its potency in shipment (Jouveau-Dubreuil 1920, 75). For preservation in summer, it was kept in a large thermos with a wide opening, surrounded by ice, maintaining a temperature a few degrees below zero. The Institute utilized an effective cooling device, "the Refrigerant." It was maintenance-free and required no chemical supplies for its operation. During winter, the Institute stored the vaccine at room temperature in the laboratory. The favorable climate helped to maintain the potency of the glycerin vaccine (ibid., 73).

Acting upon their knowledge of microbiology in making the local vaccine, the Chengdu Pastorians adapted to the local environmental circumstances in their actual practices of vaccine production, especially in accounting for the local specificity of animals and climate. This adaptation included vaccine production drawing upon various foreign vaccine strains for local use, adopting local animals such as heifers and water buffaloes as better sources of vaccine, and taking advantage of the local mild climate in preserving the glycerin vaccine.

\section{Disseminating the Jennerian Vaccine: Compromise and Collaboration}

Smallpox was the primary concern of the Pastorians' public health campaigns in the Southwest of China. Whereas Western medicine employed the germ theory of disease and immunization as a means of building a defense system against smallpox, traditional Chinese medicine since the sixteenth century construed variolation as a process of inducing a $q i$ similar to but milder than that of the patient afflicted with naturally

\footnotetext{
21 “Au Sujet de la Cession de Certains Produits à Titre Gratuit au Poste Médical de Tchentoufou,” 29/01/1910, 3, INDO GGI (Fonds du Gouvernement général de l'Indochine) 32823, Archives Nationales d'Outre Mer.
} 
occurring smallpox. ${ }^{22}$ It was meant to expel from the body the fetal toxin that had been inherited from birth. According to modern medicine, variolation induced immunity against smallpox by administering the same agent acquired from human smallpox scabs. Since the late eighteenth century, Jennerian vaccination adapted the variolation principle but used a less-virulent agent obtained from the arm-to-arm method, by extracting pustule lymph from a previously vaccinated person and transmitting it to another about to be vaccinated. From the early nineteenth century on, the vaccine was produced from retro-vaccinated animal lymph by inoculating animals with the human vaccine virus. Jennerian vaccination practice was transmitted to China in the beginning of the nineteenth century. From then on, Chinese vaccinators employed Sinicized methods similar to Jennerian vaccination but retained their explanation of smallpox aetiology from the pre-modern time, as due to the combination of fetal toxin and seasonal vapor (Qiu Xi [1817] 2002). The French Pastorians in China located their vaccination principle in the lineage of Chinese variolation and Jennerian vaccination. While practicing in China, the Pastorian-trained colonial physicians respected the Chinese ways of vaccination, as long as they were as effective at preventing smallpox as their customary practice.

Upon taking over the Pasteur Institute of Chengdu as its director in 1911, JouveauDubreuil realized that it was best not to compete, but to collaborate with local Chinese practitioners. He invited them to the laboratory at the Pasteur Institute and demonstrated the manufacture of the vaccine, explaining its properties and application. He particularly emphasized the quality of the vaccine. Local Chinese practitioners at a time of political turmoil found it hard to acquire and preserve the substance of inoculation. Jouveau-Dubreuil expected to attract them with the advantages of a readily available and swiftly replenishable active vaccine. He succeeded partially. As early as the beginning of 1913, about a dozen local Chinese practitioners applied regularly for their supply of vaccine, and in 1914 about forty of them numbered among the Institute's customers (Jouveau-Dubreuil 1920, 66-67). These Chinese practitioners, most of whom started out as variolators before becoming vaccinators, played an important role in reaching the areas where no local physicians were available.

\footnotetext{
${ }^{22}$ The concepts of smallpox aetiology in traditional Chinese medicine during pre-modern China had changed over time. The concept followed the Inner Canon of the Yellow Emperor (Huangdi Neijing 黃帝內經), the authoritative Chinese medical source since the first century BCE, and attributed disease to heteropathic qi (xie $q i$ 邪氣), a disorderly and dysfunctional flow of vital force. From the fourth to the tenth century, smallpox was thought to be caused by the cold in winter or unseasonable qi. After the tenth century, it gradually became endemic among children and was believed to have originated from two primal causes, fetal toxin (tai $d u$ 胎毒) as the internal cause, and seasonal vapor (shi qi 時氣) as the external one. Fetal toxin was considered heat toxin, derived from contaminated matter generated from the excessive diet or sex during pregnancy, given to the infant by its mother, or father, or by both. Seasonal vapor was believed to be caused by disorderly climatic conditions that would stimulate the fetal toxin inside the body, go into the pores through the circulation tracts, and develop into smallpox. When the smallpox seasonal vapor emerged, everyone could be affected except those who had had smallpox (see Chang 2000, 27-35).
} 
These Chinese vaccinators who collaborated with Jouveau-Dubreuil in Sichuan revised the vaccine content by using two kinds of substance as vaccine. For the first, they collected the smallpox scabs from vaccinated children, dried them, and mixed them with breast milk or water. For the second, they used the glycerin lymph emulsion produced in the Pasteur Institute of Chengdu, which they claimed would ensure the "purity" of the vaccine. These two kinds of mixtures were both called "nious-too" (contemporary spelling) 牛痘, cow vaccine, without distinguishing the original sources of the pathological agent, either from the locally collected smallpox scabs or the glycerin lymph emulsion supplied by the Pasteur Institute of Chengdu ${ }^{23}$ (ibid., 75; Freeman 1910, 216).

Local practitioners also reconfigured the application of the vaccine. Some of them administered vaccination through the nose, by soaking a cotton ball in the Jennerian vaccine purchased from the Pasteur Institute of Chengdu, or in the mixture of pulverized scabs and water or breast milk, before placing it into one nostril, usually the left nostril of a boy and right of a girl (Jouveau-Dubreuil 1920, 75). The nasal application conformed to the technique of Chinese variolation. Others placed the vaccine into incisions on the arms. Normally the Pasteur Institute of Chengdu produced three centigrams of glycerin pulp per package, which might suffice for two people in France. Since Chinese practitioners in Sichuan usually vaccinated in three places by making small incisions along the meridian channel on each arm, they needed more vaccine. The Institute accommodated their practices by increasing the vaccine supply. These Chinese practitioners called such a procedure of vaccination "the new method," or "the European way" (ibid.). However, upon a closer look, this procedure is neither new, nor European. In fact, it is similar to variolation that the Chinese had long practiced for preventing smallpox.

With the revision of the vaccine content and reconfiguration of the application, we can conclude that the composition and production of vaccine constituted only one part of the vaccination practice. Just about everything else diverged from the European norm. Local Chinese practitioners did not recognize a clear-cut division between variolation and vaccination. They used the vaccine purchased from the Pasteur Institute but still applied the theory and techniques of variolation. The local Chinese practitioners, upon whom the French Pastorians relied for disseminating vaccination, demonstrated medical diversity and a pragmatic approach, incorporating various local medical and social practices. ${ }^{24}$ These practices neglected the germ theory of disease,

\footnotetext{
${ }^{23}$ Similar practices took place in the Southwest of China and in Tonkin, where variolation was practiced as well. Dr. R. L. Sircar observed that a vaccinator's work was unpopular among the people on account of many children suffering from blood poisoning or going blind after vaccination. Sircar suspected that either the lymph or the scales might have been infected with septic matter, or the lancet must have been dirty. He admitted that these cases had brought discredit on vaccination and prejudiced people's minds (Sircar 1912, 318-319).

${ }^{24}$ Similarly, in regard to the discussion of Chinese medical diversity, see Rogaski's Hygiene Modernity on weisheng 衞生 (Hygiene Modernity). She observed that medical diversity allowed the Chinese to adopt, alter, or reject the content of Western medicine in Tianjin (Rogaski 2004).
} 
while incorporating Chinese medical theories such as the environmental influence on the timing of vaccination, configuration of $q i$, individual bodily constitution, diet, and rituals of worshipping the Smallpox Goddess.

The Pastorians worked with local Chinese people by incorporating social practices originating from variolation. The most notable example was the crucial choice of timing for vaccination, to coincide with that favored for variolation. The Chinese variolated in the spring, because the temperature was mild and nature was growing. They believed that under these conditions the inoculation substance would be more effective at expelling the fetal toxin. This concern for timing was deeply ingrained. In the laboratory at the Pasteur Institute of Chengdu, there was a Chinese lunar calendar, which the French physicians consulted to determine when local people were most willing to be vaccinated, and conducted their services and stocked their vaccine accordingly (Jouveau-Dubreuil 1921, 96).

The Chinese had worshipped smallpox deities since the sixteenth century as a crucial ritual for preventing smallpox. The local people in Sichuan worshipped the Smallpox Goddess whenever they had their children variolated and continued the ritual for vaccination. Ordinary people went to the temple to pray for a good vaccination, whereas a well-off family set up an altar at home and worshiped the Smallpox Goddess until the vaccinated child recovered.

Many representations of these deities were employed as protectors of the afflicted, the variolated, and the vaccinated patients into the twentieth century. Specifically in Sichuan, there existed three accounts of smallpox deities. One was the Smallpox Goddess (Dou Shen Niangniang 痘神娘娘) from Emei Mountain in Sichuan in the tenth century. Another account by Yue Jun in 1792 involved three fairy sisters (Ma Niangniang 麻娘娘), also from Emei Mountain in Sichuan. The rituals and religious regimes revealed in historical sources claim these three fairies to be related to the Smallpox Goddess. During the course of smallpox, the family had to follow the worship ritual and a strict regimen, as well as the cleanliness of dress, polite manner of speaking, and pious attitude. These deities acted as supervisors of traditional rules and further facilitated the recovery of the patient (Chang 1996, 106-121).

The local people in Sichuan worshipped the Smallpox Goddess during vaccination. The Smallpox Goddess's birthday, also called "All Flowers' Day," was commonly celebrated in March, during spring according to the Chinese lunar calendar. Just as a flower bud was thought to open on an auspicious day, so it was believed that vaccination done on that day was bound to take or "open" smallpox, which was called "tianhua" 天花, literally meaning "heaven's flowers" with an auspicious connotation. Many local people chose to have themselves or their children vaccinated at this particular time. The belief in the Smallpox Goddess and the Chinese idea of the nature of spring inspired the local people to get vaccinated in spring. The Pastorians in Chengdu accommodated this preference in order to disseminate vaccination (Jouveau-Dubreuil 1921, 96). 


\section{Conclusion: Pastorism in the Southwest of China}

Before identifying the particular patterns of Pastorian practices in China, especially at the Pasteur Institute of Chengdu, we must recognize that the Pastorian principles, which constituted Pastorism, have become established in France and expanded elsewhere in the world, with various local modifications, since the late nineteenth century. The Pastorians studied in this paper abided by the Pastorian principles in their research and public health work, albeit evincing a special concern for, and making appropriate accommodations to, local conditions. Pastorism began with germ theory of disease, which was associated with immunization. Pastorian immunization proceeded from the development of a vaccine (or serum) using the attenuated form of the microorganism otherwise identical with or related to the microorganism that causes the disease, and the application of this practice to public health. Thus Pastorian hygiene and the concept of contagion has been aptly characterized as bacteriologically centered, aiming to prevent or contain the spread of infectious diseases, including smallpox.

Bearing in mind this core feature of Pastorism, we turn to its particular applications in the Southwest of China. Although the Chengdu Pastorians faced numerous obstacles, their success in producing vaccine and disseminating vaccination complemented the French imperial ambition to extend its sphere of influence in this region. It conformed to the French colonial policy of indirect imperialism, focusing on scientific and medical imperialist projects, which were meant to spread French cultural influence to benefit the local population without imposing direct colonial rule. In addition, such indirect imperialist measures enabled and promoted the mobility and circulation of colonial physicians, laboratory materials such as vaccine strains and scientific equipment, and medical reports, moving back and forth between France and China, often through French Indochina. Such mobility resulted from indirect imperialism, advanced mutual accommodation, compromise, and collaboration that occurred in alliance between the French Pastorians and local Chinese practitioners.

In the context of such indirect imperialism, the Pastorians' accommodation of local environmental factors, cultural customs, and medical practices, was necessary to achieve the goals of their medical mission. On the one hand, they accounted for local environmental specificities, such as climate, geographical distance, as well as the acclimatization of the local animal hosts and the circulation of the vaccine strains, for vaccine production and dissemination. In selecting animal vaccine producers, the French Pastorians in Chengdu found that the local water buffalo in Sichuan resisted infection much better than its counterpart in French Indochina, where Calmette discovered the advantage of local water buffaloes and subsequently used them as the standard source of vaccine production in the Far East. The Chengdu Pastorians also discovered that local Sichuan heifers could serve as a dependable source of vaccine when water buffaloes were scarce. In the process of acquiring these local animals, the Pastorians had to negotiate with local Muslim farmers and accommodate disparate cultural perceptions and attitudes. 
The use of local heifers was further confirmed by the study of Yuan Junchang, a Chinese-national Pastorian studying at the Pasteur Institute of Paris in the late 1920s. Yuan completed his thesis on a comparative study of the strains of anti-smallpox vaccine. In identifying the condition wherein the anti-smallpox vaccine could avoid spontaneous decay and remain potent, he concluded that the glycerin heifer pulp specially developed and preserved in tropical countries would serve as the most effective vaccine against smallpox. Yuan's method yielded an effective glycerin heifer vaccine, which solved the logistic and preservation issues. His finding comported with the use of heifers as an effective animal source to acquire vaccine at the Pasteur Institute of Chengdu. The League of Nations subsequently promoted such usage of the heifer pulp (Yuan 1929, 14-18 and 54). The nature of Yuan's practices, taking account of environmental factors in his scientific work, was part of Pastorian practices shared within the Pastorian community.

The accommodation of Pastorian practices also took form in the political and socio-cultural aspects of their work. The Pastorians conducting Jennerian vaccination in Chengdu had to compromise and collaborate with local Chinese practitioners in disseminating vaccination that incorporated traditional Chinese variolation practices within its procedure, in addition to working with the local Chinese authorities and Catholic missionaries.

The compromises between Chengdu Pastorians and local Chinese practitioners demonstrated the ways pragmatic methods aided in resolving epistemologically incompatible understanding of immunity and contagion. Such divergent ideas stemmed from a different understanding of smallpox aetiology and transmission. The Pastorians believed that smallpox was caused by pathogen and transmitted by direct contact, whereas the Chinese believed that smallpox was caused by the combination of fetal toxin and seasonal vapor, and was mainly transmitted by the latter. The Chinese believed that immunity against smallpox could be achieved only through a material change in substance, namely the expulsion of impurities from the body. By contrast, the Pastorians stressed a dynamic change in function, namely the increased ability of the organism to resist the smallpox pathogen. Among colonial physicians, only a few like Regnault, came close to understanding the Chinese idea of smallpox transmission by observing Chinese variolation practices. Such discrepancy of epistemological principles, however, did not diminish the smallpox prophylaxis carried out by the collaboration between the French Pastorians and Chinese vaccinators. In this period, it appeared that aside from the education at the Chinese Medical School in Chengdu, the Chengdu Pastorians did not force the Chinese to accept their view of germ theory and the mechanism of immunization, even as they accepted the Chinese vaccination practices, based on the Chinese understanding of smallpox aetiology. However, persuading their local patients to get revaccinated became one of their ensuing and enduring challenges.

In actual practice, the local Chinese practitioners did not disseminate vaccination in a straightforward adoption of the vaccine produced by the Pasteur Institute of Chengdu. Instead, they revised the content of the vaccine and reconfigured the vaccination 
method to incorporate Chinese medical theories and variolation techniques. The Chengdu Pastorians also accommodated Chinese social customs in their vaccination practices, including the alignment of vaccination with the timing of variolation practices in spring and ritual worship of the Smallpox Goddess. Thus the nature of the Pastorian works in Chengdu exemplifies a mutual compromise and collaboration between the French and the Chinese at the level of actual practice.

The scientific perception of accommodation, shown in this paper, had changed over time. The year of 1929 was the turning point. Through the first three decades of the twentieth century, the Chengdu Pastorians successfully produced the Jennerian vaccine locally and provided an ample supply of it to the Southwest of China. They largely relied on the local Chinese practitioners to disseminate vaccination. Accommodating the "neither new, nor European" practices of the local Chinese practitioners, with whom the Chengdu Pastorians chose not to compete but to collaborate, became the next best strategy. In the view of physicians in China prior to the 1929 confrontation between the practitioners of Western medicine and their traditional competitors, such practices were neither ill-conceived nor doomed to fail. ${ }^{25}$ However, for the European Pastorians, their accommodation of these practices did not always stand on solid scientific ground, as there was no empirical evidence for the correlation between these practices and the success rate of vaccination. However, the accommodation strategy worked, as measured by the decreasing incidence of smallpox.

The public health efforts relating to smallpox prevention in the Southwest of China during this period were based on the network established among the French medical mission in Chengdu and the cooperating Chinese practitioners, as well as other foreign medical service providers, with a passive endorsement by the local Chinese government. The dissemination of vaccination did not depend on a government initiative. The Pastorian contribution mainly consisted in the production and supply of Jennerian vaccine. However, the technical capacity for vaccine production did not guarantee a wide dissemination of vaccination. Aside from the French physicians and the students from the Chinese Medical School practicing vaccination in the French Catholic Missionary Hospital, the French Clinic (maison de santê), and the Pasteur Institute of Chengdu, most of vaccination dissemination depended on the missionaries, other European and American hospitals, and Chinese practitioners, not only in Sichuan, but also in the surrounding provinces. ${ }^{26}$ Even though we can take the growing number of administered vaccine doses to imply the increase of its production and distribution, we can only infer that the scope of vaccination correlated with this increase, especially as performed in rural areas by the Chinese practitioners. The actual practices of

\footnotetext{
${ }^{25}$ Regarding the 1929 confrontation between the practitioners of Western medicine and traditional Chinese practitioners, Sean Hsianglin Lei is among many scholars who have thoroughly studied the subject (see Lei 2002; Lei 2014, 97-119).

${ }^{26}$ A. Gervais, "Rapport sur la Clinique Médicale Française de Tchentou pour 1925,” 06/03/1925, 171-173, Chine 499, Série E, Asie, MAEP.
} 
vaccination involved revising the Jennerian vaccine, along with reconfiguring the very practice of vaccination to conform to the existing social practices of variolation. These practices differed in essence from their European prototypes. The mutual compromises and collaboration between French Pastorians and Chinese practitioners were the keys to their acceptance by the local society.

\section{Archival Materials}

"Au Sujet de la Cession de Certains Produits à Titre Gratuit au Poste Médical de Tchentoufou." 29/01/1910. INDO GGI (Fonds du Gouvernement général de l'Indochine) 32823. Archives Nationales d'Outre Mer.

“Devis et Lettre de P. Lequeux, Paris.” 25/09/1907, 77-79, Chine 300, Nouvelle Série (NS). Archives du Ministère des Affaires Étrangères, La Courneuve, Paris (MAEP).

Esserteau, Jean-Paul. "Rapport pour l'Année 1909." Chine 656, NS. MAEP.

Esserteau, Jean-Paul. "Rapport pour l'Année 1910." Chine 656, NS. MAEP.

Gervais, Albert. "Rapport sur la Clinique Médicale Française de Tchentou pour 1925.” 06/03/1925, 166-177, Série E, Asie, 499. MAEP.

Jouvelet, Pierre. "Rapport sur le Fonctionnement de l'Institut Bactériologique de Tchentou pendant l'Année 1926." 22/02/1927, 167-179, Chine, Série E, Asie, 500. MAEP.

Legendre, Aimé-François. "Rapport du Dr. Legendre au Sujet de l'Hôpital Catholique de Tchen-tou, du Docteur Aimé-François Legendre au Ministre des Affaires Etrangères." 26/05/1908, Chine 651, NS. MAEP.

"Lettre du Docteur A. Legendre au Consul Général à Tchentou - Annexe à la lettre no. 43, en date du 23 Septembre 1907, du Consulat Général de France à Tchentou à la Direction Politique." 21/09/1907, Chine 656, NS. MAEP.

"Projet d'Installation d'un Institut Pasteur à Tchen-tou." CHN01, 004. Archives de l'Institute Pasteur.

"Organisation d'un Institut Pasteur à Tchentou." Chine 651, NS. MAEP.

“The Reactions Which Follow Smallpox Vaccination.” Baltimore Health News 8. 4-5 (1936). U1-16-2654. Shanghai Municipal Archives.

\section{Published References}

Abrams, L., and D. J. Miller. 1976. "Who were the French Colonialists? A Reassessment of the Parti Colonial, 1890-1914." Historical Journal 19(3):685-725.

Anderson, Warwick. 2008. The Collectors of Lost Souls: Turning Kuru Scientists into Whitemen. Baltimore: The Johns Hopkins University Press.

Andrews, Bridie. 2012. "In Republican China, Public Health by Whom, for Whom?” In Science, Public Health and the State in Modern Asia, edited by Liping Bu, Darwin H. Stapleton, and Ka-che Yip, 177-194. New York: Routledge.

Andrews, Bridie. 2014. The Making of Modern Chinese Medicine, 1850-1960. Vancouver: UBC Press.

Barbier, Hervé. 1997. "Les Canonnières du Yang-tsé, 1900-1941." In La France en Chine, 1843-1943, edited by Jacques Weber, 131-144. Nantes: Presse Académique de l'Ouest.

Bastid-Bruguière, Marianne. 1991. "Instituts et Laboratoires Pasteur en Chine avant 1949." In L'Institut Pasteur: Contributions à son Histoire, edited by Michel Morange, 253-268. Paris: La Découverte.

Benedict, Carol. 1996. Bubonic Plague in Nineteenth-Century China. Stanford: Stanford University Press.

Bodard, Lucien. 1999. Monsieur le Consul. Paris: B. Grasset.

Bonavia, David. 1995. China's Warlords. Oxford: Oxford University Press. 
Bretelle-Establet, Florence. 2002. La Santé en Chine du Sud, 1898-1928. Paris: CNRS Éditions.

Bullock, Mary Brown. 1980. An American Transplant: The Rockefeller Foundation and Peking Union Medical College. Berkeley: University of California Press.

Calmette, Albert, and G. Lepinay. 1908. "Mémoire sur l'Organisation et le Fonctionnement du Service de la Vaccine en Cochinchine de 1867 à 1890." In Rapport Général Présenté par l'Académie de Médecine sur les Vacinations et Revaccinations pendant l'Année 1892. Paris: Masson.

Chakrabarti, Pratik. 2012. Bacteriology in British India. Rochester: University of Rochester Press.

Chang, Chia-Feng. 1996. "Aspects of Smallpox and Its Significance in Chinese History." Ph.D. diss., University of London School of Oriental and African Studies.

Chang, Chia-Feng. 2000. "Dispersing the Foetal Toxin of the Body: Conceptions of Smallpox Aaetiology in Pre-Modern China." In Contagion: Perspectives from Pre-Modern Societies, edited Lawrence I. Conrad and Dominik Wujastyk, 23-38. Burlington VT: Ashgate Publishing Company.

Chang, Chia-Feng. 張嘉鳳. 2007. 十九世紀初牛痘的在地化 (“Shijiu shiji chu niudou de zaidi hua” [Localization of Vaccination in the Nineteenth Century]). 中央研究院歷史語言研究所集刊 (Zhongyang yanjiuyuan lishi yuyan yanjiusuo jikan [Journal of Institute of History and Philology, Academia Sinica]) 78(4):755-812.

Chen, Yuan 陳垣. 1993. 牛痘入中國考略 (“Niudou ru Zhongguo kao lüe” [The Brief History of Vaccination Dissemination in China]). In陳援菴先生全集 (Chen Yuanan xiansheng quanji [Collection of Mr. Chen Yuanan], 16:776-783. Taipei: Xin wen feng chuban gongsi.

Creager, Angela. 2001. The Life of a Virus: Tobacco Mosaic Virus as an Experimental Model, 1930-1965. Chicago: University of Chicago Press.

Cun, cui xueshe 存萃學社, ed., 1977. 民國以來四川動亂史料彙輯 (Minguo yila Sichuan dongluan shilao huiji [Collection of Historical Materials on Sichuan Political Turbulence in Republican Era]). Hong Kong: Dadong tushu gongsi.

De Fleury, Maurice. 1895. Pasteur et les Pastoriens. Paris: Rueff.

Dedet, Jean-Pierre. 2000. Les Instituts Pasteur d'Outre-Mer: Cent Vingt Ans de Microbiologie Française dans le Monde. Paris: L'Harmattan.

Fan, Xingzhun 范行準. 1953. 中國預防醫學思想史 (Zhongguo yufang yixue sixiangshi [Chinese Preventive Medical History]). Beijing: Renmin weisheng chubanshe.

Fang, Xiaoping. 2012. Barefoot Doctors and Western Medicine in China. Rochester: University of Rochester Press.

Faure, Marguerite. 1991. “Cent Années d'Enseignement à l'Institut Pasteur." In L'Institut Pasteur: Contributions à son Histoire, edited by Michel Morange, 62-74. Paris: La Découverte.

Freeman, C. W. 1910. "Report on the Health of Chungking for the Year Ending $30^{\text {th }}$ September, 1909." Chinese Medical Journal 24.2: 215-217.

Kuang, Sanji 匡珊吉. 1991. 四川軍閥史 (Sichuan junfa shi [History of Sichuan Warlords]). Chengdu: Sichuan renmin chubanshe.

Gervaise, Albert. 1934. Medicine Man in China. Translated by Vincent Sheean. New York: Frederick A. Stokes Company.

Gold, Thomas, ed., 2002. Social Connections in China: Institutions, Culture, and the Changing Nature of Guanxi. Cambridge: Cambridge University Press.

Guénel, Annick. 1999. "The Creation of the First Overseas Pasteur Institute, or the Beginning of Albert Calmette's Pastorian Career." Medical History 43(1):1-25.

Hanson, Marta. 2010. "Conceptual Blind Spots, Medical Blindfolds: Controlling 2003 SARS Risk in Taiwan." In Health and Hygiene in Chinese East Asia: Policies and Publics in the Long Twentieth Century, edited by Angela Ki Che Leung and Charlotte Furth, 228-254. Durham: Duke University Press.

Harrison, Henrietta. 2012. "Rethinking Missionaries and Medicine in China: The Miracles of Assunta Pallota, 1905-2005." Journal of Asian Studies 71(1):127-148.

Harrison, Henrietta. 2013. The Missionary's Curse and Other Tales from a Chinese Catholic Village. Berkeley: University of California Press. 
Héraut, Louis-Armand. 2006. "La Médecine Militaire Coloniale Française. Une Aventure Médicale de Trois Quarts de Siècle, 1890-1968." Histoire des Sciences Médicales 40(4):381-392.

Institut de Vaccine Animale. 1895. Institut de Vaccine Animale: 8 Rue Ballu, Paris. Paris: S. N.

Jouveau-Dubreuil, Henri. 1920. "Service de la Vaccine à l'Institut Pasteur de Tchen-Tou." Annales de Médecine et de Pharmacie Coloniales: 64-77.

Jouveau-Dubreuil, Henri. 1921. "La Variolisation au Setchouen." Bulletin de la Société de Pathologie Exotique 14:93-97.

Kumar, Deepak. 1997. "Unequal Contenders, Uneven Ground: Medical Encounters in British India, 1820-1920." In Western Medicine as Contested Knowledge, edited by Andrew Cunningham and Bridie Andrews, 172-190. Manchester: Manchester University Press.

Lachenal, Guillaume. 2011. "The Intimate Rules of the French Cooperation: Morality, Race and the Postcolonial Division of Scientific Work at the Pasteur Institute of Cameroon." In Evidence, Ethos and Experiment: The Anthropology and History of Medical Research in Africa, edited by Wenzel Geissler and Catherine Molyneux, 373-400. New York: Berghahn Books.

Legendre, Aimé-François. 1905. Le Far-West Chinois: Deux Années au Setchouen. Paris: Librairie Plon.

Lei, Sean Hsianglin. 2002. "How Did Chinese Medicine Become Experiential?” Positions 10(2): 333-364.

Lei, Sean Hsianglin. 2010. "Sovereignty and the Microscope: Constituting Notifiable Infectious Disease and Containing the Manchurian Plague (1910-1911)." In Health and Hygiene in Chinese East Asia: Policies and Publics in the Long Twentieth Century, edited by Angela Ki Che Leung and Charlotte Furth, 73-106. Durham: Duke University Press.

Lei, Sean Hsianglin. 2014. Neither Donkey Nor Horse: Medicine in the Struggle over China's Modernity. Chicago: University of Chicago Press.

Leung, Angela Ki Che. 1996. "Variolation and Vaccination in Late Imperial China, ca. 1570-1911." In Vaccinia, Vaccination and Vaccinology: Jenner, Pasteur and their Successors, edited by S. Plotkin and B. Fantini, 65-71. Paris: Elsevier.

Leung, Angela Ki Che. 2008. "The Business of Vaccination in Nineteenth Century Canton.” Late Imperial China 29(1 Supplement):7-39.

Leung, Angela Ki Che. 梁其姿. 2012. 面對疾病: 傳統中國社會的醫療觀念與組織 (Miandui jibing: chuantong Zhongguo shehui de yiliao guannian $y u$ zuzhi [In Face of Illness: Medical Concepts and Institutions in Traditional Chinese Society]). Beijing: Zhongguo remin daxue chubanshe.

Li, Shengjen. 1999. "British Imperial Medicine in Late Nineteenth-Century China and the Early Career of Patrick Manson.” PhD diss., University of London.

Liu, Chien-Ling. 2016. "Relocating Pastorian Medicine: Accommodation and Acclimatization of Medical Practices at the Pasteur Institutes in China, 1899-1951.” PhD diss., University of California, Los Angeles.

Liu, Michael Shiyung. 2009. Prescribing Colonization: the Role of Medical Practice and Policy in Japan-Ruled Taiwan. Ann Arbor: AAS.

Lock, Margaret and Patricia Kaufert. 2001. "Menopause, Local Biologies, and Cultures of Aging." American Journal of Human Biology 13:494-504.

Löwy, Ilana. 1990. "Yellow Fever in Rio de Janeiro and the Pasteur Institute Mission (1901-1905): The Transfer of Science to the Periphery." Medical History 34(2):144-163.

Mouillac, Marie Joseph. 1908. "Le Poste Medical de Tchentou." Annales d'Hygiène et de Médecine Coloniales 11:5-29.

Moulin, Anne-Marie. 1991. Le Dernier Langage de la Médicine: Histoire de l'Immunologie de Pasteur au SIDA. Paris: Presse Universitaire de France.

Moulin, Anne-Marie. 1992. "Patriarchal Science: the Network of the Overseas Pasteur Institutes." In Science and Empire, edited by Patrick Petitjean, Catherine Jami, and Anne-Marie Moulin, 307-322. London: Kluwer Academic Publishers. 
Moulin, Anne-Marie. 1994. "Bacteriological Research and Medical Practice in and out of the Pastorian School." In French Medical Culture in the Nineteenth Century, edited by Ann La Berge and Mordechai Feingold, 327-349. Amsterdam: Atlanta GA.

Moulin, Anne-Marie. 1995. "The Pasteur Institutes between the Two World Wars. The Transformation of the International Sanitary Order." In International Health Organisations and Movements, 1918-1939, 244-265. Cambridge: Cambridge University Press.

Moulin, Anne-Marie. 2004. "The Pasteur Institute's International Network: Scientific Innovations and French Tropisms." In Transnational Intellectual Networks: Forms of Academic Knowledge and the Search for Cultural Identities, edited by Christophe Charle Jügen Schriewer, and Peter Wagner, 135-164. Frankfurt: Campus Verlag GmbH.

Moulin, Anne-Marie, ed., 1996. L'aventure de la vaccination. Paris: Fayard.

Moulin, Anne-Marie, Jerald Hage, and Jonathon More. 2008. "Transformational Organizations and Institutional Change: the Case of the Institut Pasteur and French Science." Socio-Economic Review 6(2):313-336.

Osborne, Michael. 2014. The Emergence of Tropical Medicine in France. Chicago: University of Chicago Press.

Pelis, Kim. 1997. "Prophet for Profit in French North Africa: Charles Nicolle and the Pasteur Institute of Tunis, 1903-1936." Bulletin of the History of Medicine 71(4):583-622.

Pelling, Margaret. 2001. "The Meaning of Contagion: Reproduction, Medicine and Metaphor." In Contagion: Historical and Cultural Studies, edited by Alison Bashford and Claire Hooker, 15-38. London: Routledge.

Peltier, Maurice. 1947. "Yellow Fever Vaccination, Simple or Associated with Vaccination against Smallpox, of the Populations of French West Africa by the Method of the Pasteur Institute of Dakar." American Journal of Public Health 37:1026-1032.

Qiu, Xi 邱熺. [1817]2002. 引痘略 (Ying dou lüe [Introduction of Inducing Smallpox by Cowpox Vaccine]), 1. In 續修四庫全書 (Хихiu Siku quanshu), Zi Bu 5, Yijia Lei, 1012. Shanghai: Shanghai guji chubanshe.

Qiu, Zhonglin. 邱仲麟. 2006. 明清的人痘法一地域流佈 “知識傳播與疫苗生產 (“Ming Qing de ren dou fa: diyu liubu, zhishi chuanbo yu yimiao shengchan" [Smallpox Inoculation in Ming-Qing China: Regional spread, Knowledge Dissemination, and Vaccine Production]). 中央研究院歷史語言研究 所集刊 (Zhongyang yanjiuyuan lishi yuyan yanjiusuo jikan [Journal of Institute of History and Philology, Academia Sinica]) 77(3):451-516.

Raj, Kapil. 2007. Relocating Modern Science: Circulation and the Construction of Knowledge in South Asia and Europe, 1650-1900. New York: Palgrave Macmillan.

Rheinberger, Hans-Jörg. 2016. "Patterns of the International and the National, the Global and the Local in the History of Molecular Biology." In The Local Configuration of New Research Fields, edited by Martina Merz and Phillippe Sormani, 193-204. Cham, Switzerland: Springer International Publishing.

Regnault, Jules. 1901. Médecine et Pharmacie chez les Chinois et chez les Annamites. Paris: A. Challamel.

Rogaski, Ruth. 2004. Hygienic Modernity: Meanings of Health in Treaty Port China. Berkeley: University of California Press.

Rosenberg, Clifford. 2012. "The International Politics of Vaccine Testing in Interwar Algiers." American Historical Review 117(3):671-697.

Sheridan, James E. 1977. China in Disintegration. New York: Free Press.

Sichuansheng wenshi yanjiu guan 四川省文史研究館 [Sichuan Research Institute of Culture and History], ed., 2011. 民國四川軍閥實錄 (Minguo Sichuan junfa shilu [History of Sichuan Warlords in Republican Era]). Chengdu: Sichuan renmin chubanshe.

Sircar, R. L. 1912. "Report on the Health of Tengyueh for the Two Years Ended the 31 ${ }^{\text {st }}$ March, 1911." Chinese Medical Journal 26(1):318-319.

Strachan, John. 2006. “The Pasteurization of Algeria?” French History 20(3):260-275.

Taylor, Kim. 2005. Chinese Medicine in Early Communist China, 1945-63. New York: Routledge Curzon. 
Wang, Jessica. 2013. "A Tale of Three Laboratories: Rabies Vaccination and the Pasteurization of New York City, 1885-1920." Paper presented in the History of Science Colloquium at UCLA, 1 April 2013. Wilson, Adrian. 2014. Ideas and Practices in the History of Medicine, 1650-1820. New York: Routledge.

Wong, K. Chimin and Lienteh Wu. 1973. History of Chinese Medicine: Being a Chronicle of Medical Happenings in China from Ancient Times to the Present Period. New York: AMS Press.

Yuan, Singtsong. 1929. Étude Comparative des Souches de Vaccine Antivariolique. Paris: Librairie M. LAC. 